\title{
The Taolimiao-Alashan Nur: its Wetland Bird Community and the Wetland Habitat Assessment ${ }^{*}$
}

\author{
HE FENQI ZHANG YINSUN \\ Institute of Zoology, Academia Sinica, Beijing 100080, China \\ (Received September 4, 1996)
}

\section{ABSTRACT}

Results of the field work in recent years reveal that the Taolimiao-Alashan Nur is of specific significance to the survival of the Relict Gull Ordos subpopulation while the wetland birds occurring there represent concentratedly and indicatively the characteristics of the wetland bird community in desert of Ordos; as in July of 1992 China became the contract nation of the Convention on Wetlands of International Importance especially as Waterfowl Habitat (The Ramsar Convention), the study also presents an assessment on the wetland habitat of the T-A Nur following the Criteria recommended by the Convention and suggests that the T-A Nur following the relevant articles/items of the Criteria might be considered as an important wetland locality in China and hence to be listed on List of Wetlands of International Importance.

Key words Taolimiao-Alashan Nur, wetland bird community, wetland habitat assessment, wetland of international importance

\section{Introduction}

Studies on birds in Ordos were initiated in the project of investigation on the avifauna of Inner Mongolia Autonomous Region. On 29th April 1987, skins of a pair of gulls were collected at a small lake not far from the Taolimiao-Alashan Nur, to which it was later on, by kind help of Dr. Martin Williams, identified as the Relict Gull (Larus relictus) (Duff et al. 1991).

In May of 1990, a large breeding colony of the Relict Gull was found at the T-A Nur, then regular field observations on the gull and on other wetland birds around the lake were hence started and, during 1990 1996, seventeen field observations had been undertaken with a total duration covering all the time from early April to mid-October.

\section{Geographical characters of the Taolimiao-Alashan Nur}

The Taolimiao-Alashan Nur $\left(39^{\circ} 48^{\prime} \mathrm{N}, 109^{\circ} 35^{\prime} \mathrm{E}\right)$ is a brackish lake, located on the Ordos Highland at the contiguous area of the two large deserts - Maowusu and Kubuchi.

\footnotetext{
* The authors here would like to express their sincere gratitude to the Oriental Bird Club and the Fauna \& Flora Protection Society (now Fauna \& Flora International) in UK, the American Museum of Naural History in USA, and especially the Ramsar Convention Bureau in Switzerland for the constant support that they had given onto the studies both on the Relict Guils and on assessing wetland habitats in desert of Ordos
} 
The lake is at an elevation of $1360 \mathrm{~m}$, about $6 \mathrm{~km}$ of its east-westward length and 2.5 $\mathrm{km}$ of its south-northward as the widest, with about $10 \mathrm{~km}^{2}$ of its total area, $1.0 \sim 1.2 \mathrm{~m}$ in depth with more than $3.5 \mathrm{~km}$ at deepest, and $8.5-9.0 \mathrm{pH}$ of the water.

The aquatic plants occurring in the lake are mainly Potamogeton spp., Cladophora, Ulothrix, etc.

Surroundings of the lake are mostly the stabilized sand dunes, at $1368 \sim 1392 \mathrm{~m}$ high, with poor vegetation of typical eremophytes such as Nitraria roporowskii, Oxytropis psammocharis, Artemisia ordosica, Achnatherum splencleus, Euphoria kozlowi, Pyconsteluma lateriflorum, as well as the artificial-planted windbreak woods of Salix cheilophila and Caragana korshinskii. And on low land by the lake shore is developing wet grassland of Carex duriuscula with some water here and there.

Around the lake, temperature of the year is $35.8{ }^{\circ} \mathrm{C}$ the highest and $-32.6{ }^{\circ} \mathrm{C}$ the lowest, 130 - 139 days of frost-free, and $325 \mathrm{~mm}$ of the average annual rain fall occurring more concentratedly during July and August.

There are a few islets emerged in south-westwards central lake ranging from north-east to south-west, the number and especially the actual area of those islets are much changeable due to the rain fall of the year. In 1990 1996, there are 5 7 islets. Though the number of the islets is not much varied, the total area of those islets is rather enlarged during the dry season/year as some islets connected into bigger one while new islets emerged (Fig.1).

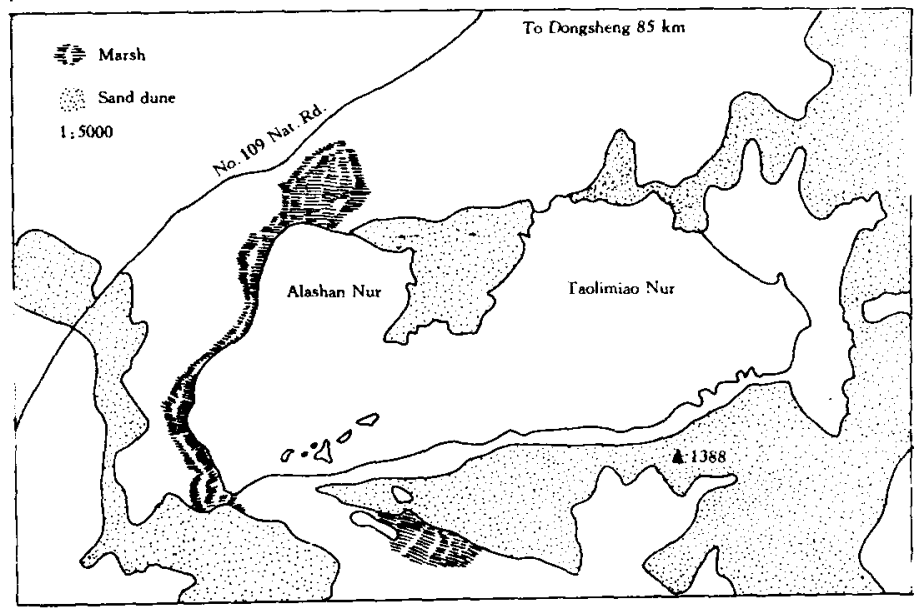

Fig. 1 The sketch map of the Taolimiao-Alashan Nur

\section{The wetland bird community at T-A Nur}

During the field work, 90 species of wetland birds have been recorded around the lake and all of them are migrants.

The wetland birds occurring at T-A Nur might be classified approximately as:

Breeders - to those birds with definite breeding records there;

Summer residents - to those birds of individuals and flocks occurring around the lake throughout the whole breeding season but no breeding records found during the field work;

Passengers/vagrants - to those birds inhabiting at the lake only for some time of the migrating season or accidentally seen at $\mathrm{T}-\mathrm{A}$ Nur.

And the different status might be observed of those breeders at T-A Nur as: 
a) Almost all the individuals there sharing in breeding, mostly those Laridae birds such as the Relict Gull, Gull-billed Tern, Common Tern, and Brown-headed Gull;

b) Though being with a somewhat stable flock since late April and/or early May, only some individuals in the flock breed at T-A Nur, the species including the Black-necked Grebe. Ruddy Shelduck, Common Shelduck, Avocet, and Black- winged Stilt;

c) Most of the birds occurring at T-A Nur for some time during the migrating season and then flying northwards while only a few individuals inhabiting and breeding there, for instance, the Little Grebe, Yellow-nibbed Duck, Gadwall, and Common Shoveller.

At T-A Nur, Colonies of the Relict Gulls play an important role, in 1990 1996, nests of the Relict Gulls make up a percentage of $87.24 \%(581: 666,1990), 57.56 \%(491: 583$, $1991), 87.56 \%(1028: 1174,1992), 62.72 \%(1509: 2406,1993), 64.26 \%(1931: 3005$, $1994), 59.48 \%(1832: 3080,1995)$, and $49.50 \%(2048: 4137,1996)$ of total nests of all the waterbirds at lake.

For the status of the Relict Gull's breeding flock at T-A Nur, it has been reported in more detail in the authors' previous work (Zhang Yinsun et al. 1991a, 1991b, 1992, 1993; He Fenqi et al. 1992, 1994; He and Zhang 1993), and no repeat here needed.

At T-A Nur, resident time of those wetland birds is about 270 days a year. The Whooper Swan is usually the earliest returnee, coming back in small flocks even as early as in late February, and the last remainders found in mid- and late November included Little Grebe, Great Crested Grebe, Whooper Swan, Ruddy Shelduck, Common Shelduck, Coot, and Black-headed Gull.

In spring season, though slightly varied, it is the main tendency that both the species and their individuals are increasing. In mid- and late May, the proportion of passengers in/ around the lake siarts declining, and to early June the species at lake are mostly breeders and/or summer residents.

During the breeding season, the amount of wetland birds that the T-A Nur constantly supporting in the last few years is at least over 5000 individuals (Table 1).

Since mid-/late August, breeders, mainly the Relict Gull and the Gull-billed Tern, with their youngsters start moving to the surrounding lakes while it is a rapid increasing of the Ruddy Shelduck, Common Pochard and Coot from outside and soon becoming the dominants in the local bird community.

And to mid-September, large quantity of passengers from the northward come into the lake making it the highest housing capacity of T-A Nur-about $20000 \sim 22000$ individuals in total of waterbirds, mostly the Common Pochards and Coots, and waders together with some large waterfowl appearing at the lake in big flock including hundreds of Swan Geese and Greylag Geese, and the Common Cormorants up to one thousand or even more.

Till late migrating season, though both the species and individuals are much reduced, the maintenance of high biomass of the lake is still remained due to the lagging of some waterfowl in large size, for instance, hundreds of the Whooper Swans.

During the field work at T-A Nur, some phenomena were observed which are of specific meaning to certain bird species, for example-

In mid-June 1991, a single bird of the Oriental White Stork (Ciconia boyciana) was found at the lake shore for several days, this is the first record of the bird so far reported 
Table 1 List of the wetland birds occurred at Taolimiao-Alashan Nur during 1990 1996

\begin{tabular}{|c|c|c|c|c|c|c|c|c|c|}
\hline \multirow[b]{2}{*}{ Species } & \multicolumn{8}{|c|}{ Month } & \multirow{2}{*}{ Status } \\
\hline & 4 & 5 & 6 & 7 & 8 & 9 & 10 & 11 & \\
\hline Podiceps ruficollis & + & + & + & + & + & + & + & + & $P$ \\
\hline$P$. auritus & + & & & & & & & & ${ }_{B}^{P}, P$ \\
\hline P. nigricollis & + & + & + & + & + & + & + & & $B, P$ \\
\hline$P$. cristatus & + & + & + & + & + & + & + & + & $S(? B)$ \\
\hline$P \cdot g r i s e g e n a$ & + & & & & & & & & $\mathrm{P}$ \\
\hline Pelecanus philippensis & + & & & & & & & & $\mathrm{P}$ \\
\hline Phalacrocorax carbo & + & + & + & + & + & + & + & & $\mathrm{S}, \mathrm{P}$ \\
\hline Ardea cinerea & + & + & + & + & + & + & + & & $\mathrm{S}, \mathrm{P}$ \\
\hline A. purpurea & + & & & & & & & & $\mathrm{P}$ \\
\hline Egretta alba & & & & & & & + & & $\mathrm{P}$ \\
\hline Nycticorax nycticorax & & & + & & & & & & $\mathrm{P}$ \\
\hline Ciconia boyciana & & & + & & & & & & $\mathrm{S}(?)$ \\
\hline Platalea Leucorodia & + & + & & & & + & + & & $\mathbf{P}$ \\
\hline Anser cygnoides & + & + & & & & + & + & & $\mathrm{P}$ \\
\hline A. fabalis & + & + & & & & & + & & $\mathrm{P}$ \\
\hline A. anser & & + & + & & & + & + & & $\mathrm{S}, \mathrm{P}$ \\
\hline A. indicus & & & + & & & & & & $\mathrm{S}(?)$ \\
\hline Cygnus cygnus & + & + & & & & + & + & + & $\mathrm{P}$ \\
\hline C. olor & & & + & & & & & & $\mathbf{P}$ \\
\hline Tadorna ferruginea & + & + & + & + & + & + & + & + & $\mathrm{B}, \mathrm{P}$ \\
\hline$T \cdot$ tadorna & + & + & + & + & + & + & + & + & $\mathrm{B}, \mathrm{P}$ \\
\hline Anas acuta & + & + & & & & & + & & $\mathrm{P}$ \\
\hline A. crecca & + & + & & & & + & + & & $\mathrm{P}$ \\
\hline A. falcata & + & + & & & & + & + & & $\mathrm{P}$ \\
\hline A. platyrhynchos & + & + & + & + & + & + & + & & $\mathrm{P}, \mathrm{S}$ \\
\hline A. puecilorhymcha & + & + & + & + & + & + & + & + & $\mathrm{B}, \mathrm{P}$ \\
\hline A. strepera & + & + & + & + & + & + & + & & $\mathrm{B}, \mathrm{P}$ \\
\hline A.penelope & + & + & + & + & + & + & + & & $\mathrm{S}, \mathrm{P}$ \\
\hline A. querquedula & + & + & + & & & + & + & & $\mathrm{P}$ \\
\hline A. clypeata & + & + & + & + & + & + & + & & $\mathrm{B}, \mathrm{P}$ \\
\hline Netta rufina & + & + & & & & + & & & $\mathbf{P}$ \\
\hline Aythya ferina & + & + & + & + & + & + & + & & $\mathrm{S}(? \mathrm{~B})$ \\
\hline A. nyroca & + & + & + & & & + & + & & $\mathrm{P}$ \\
\hline A. fuligula & + & + & & & & + & & & $\mathrm{P}$ \\
\hline A. marila & + & + & & & & + & & & $\mathrm{P}$ \\
\hline Melanitta nigra & & & + & & & & & & $\mathrm{P}$ \\
\hline Bucephala clangula & + & + & + & & & + & + & & $\mathrm{P}, \mathrm{B}$ \\
\hline Mergus albelus & + & + & & & & + & + & & $\mathrm{P}$ \\
\hline$M$. mergaser & & + & & & & & & & $\mathrm{P}$ \\
\hline Milvus korschun & & & + & + & & & + & & $P(? S)$ \\
\hline Accipiter gentilis & + & + & & & & & & & $\mathrm{P}$ \\
\hline Buteo hemilasius & & + & & & & & & & $\mathrm{P}$ \\
\hline Haliaeetus albicilla & & & & & + & & + & & $\mathrm{P}$ \\
\hline H. leucoryphus & + & & & & & & & & $P$ \\
\hline Circus spilonotus & & & + & & & & & & $\mathrm{P}, \mathrm{S}$ \\
\hline Falco vespertinus & + & + & + & + & + & + & + & & $\mathrm{S}, \mathrm{B}$ \\
\hline$F$. tinnunculus & & & + & + & + & & & & $\mathrm{S}$ \\
\hline Anthropoides virgo & + & + & + & + & + & + & + & & $\mathrm{S}(? \mathrm{~B}), \mathrm{P}$ \\
\hline Porzana pusilla & & + & + & & & & & & $\mathrm{P}$ \\
\hline Gallinula chloropus & & + & & & & & & & $\mathrm{P}$ \\
\hline Fulica atra & + & + & + & + & + & + & + & + & $S(? B), P$ \\
\hline
\end{tabular}


Table 1 (Continued)

\begin{tabular}{|c|c|c|c|c|c|c|c|c|c|}
\hline Vanellus vanellus & + & + & + & + & + & + & + & & $\mathrm{B}, \mathrm{S}$ \\
\hline$V$. cinereus & + & + & + & & & + & + & & $\mathrm{P}$ \\
\hline Pluvialls dominica & + & + & + & & & + & + & & $\mathrm{P}$ \\
\hline Charadrius dubius & + & + & + & + & + & + & + & & B \\
\hline Ch. alexandrinus & + & + & + & + & + & + & + & & $\mathbf{B}$ \\
\hline Ch. leschenaultii & & & + & & & & & & $\mathbf{P}$ \\
\hline Ch. asiaticus & & + & & & & & & & $\mathbf{P}$ \\
\hline Numenius phaeopus & + & + & & & & + & & & $\mathbf{P}$ \\
\hline N. arquata & + & + & + & & & + & & & $\mathrm{P}$ \\
\hline Limosa limosa & + & + & + & & & & & & $P(? S)$ \\
\hline Tringa erythropus & & + & + & & & & & & $\mathrm{P}$ \\
\hline$T \cdot$ totanus & + & + & + & + & + & + & + & & $\mathrm{B}, \mathrm{S}$ \\
\hline T. stagnatilis & & + & & & & & & & $\mathrm{P}$ \\
\hline T.ochropus & + & + & & & & + & & & $\mathrm{P}$ \\
\hline T. nebularia & & + & + & & & + & & & $\mathrm{P}$ \\
\hline T.glareola & + & + & & & & + & & & $\mathbf{P}$ \\
\hline$T$. hypoleucos & + & + & & & & & & & $\mathbf{P}$ \\
\hline$T$. incana & & + & & & & & & & $\mathbf{P}$ \\
\hline Arenaria interpres & + & + & + & & & + & & & $\mathbf{P}$ \\
\hline Capella gallinago & + & + & & & + & + & & & $\mathbf{P}$ \\
\hline Scolopax rusticola & + & & & & & & & & $\mathbf{P}$ \\
\hline Calidris temminckii & & + & & & & & & & $\mathbf{P}$ \\
\hline Himantopus himantopus & + & + & + & + & + & + & + & & $\mathrm{B}, \mathrm{S}$ \\
\hline Recurvirostra avosetta & & + & + & + & + & + & & & $\mathrm{B}, \mathrm{S}$ \\
\hline Glareola maldivarum & + & + & & & & & & & $\mathrm{P}$ \\
\hline Larus crassirostris & + & + & + & & & & & & $\mathbf{P}$ \\
\hline L. canus & & & + & + & & & & & $\mathrm{S}$ \\
\hline$L$. argentatus & + & + & & & & + & + & & $\mathrm{P}$ \\
\hline L. ichthyartus & + & + & & & + & + & + & & $P(? S)$ \\
\hline$L$. relictus & + & + & + & + & + & + & & & B \\
\hline L. ridibundus & + & + & + & + & + & + & + & + & $\mathrm{S}, \mathrm{P}$ \\
\hline L. brunicephalus & & + & + & + & + & + & & & B \\
\hline Chlidonias hybrida & & + & + & + & + & + & & & $\mathrm{S}(? \mathrm{~B})$ \\
\hline Ch. leucoptera & & + & & & + & + & & & $\mathrm{P}$ \\
\hline Ch. niger & & & + & & & & & & $\mathbf{P}$ \\
\hline Gelochelidon nilotica & + & + & + & + & + & + & & & B \\
\hline Hydroprogne caspia & & + & + & & & & & & $\mathbf{P}$ \\
\hline Sterna hirundo & + & + & + & + & + & + & + & & $\mathrm{B}, \mathrm{S}$ \\
\hline S. albifrons & + & + & & & & & & & $\mathbf{P}$ \\
\hline
\end{tabular}

$\mathrm{B}=$ breeder; $\mathrm{S}=$ summer resident; $\mathrm{P}=$ passerger/vagrant

occurring in desert habitat of western Inner Mongolia during the breeding season (Zhang Yinsun and He Fenqi 1992);

And, in the breeding season of 1992, 6 pairs of the Brown-headed Gulls were found on islets nesting in the Relict Gull's colonies but showing different behavior and with no hybridization with the latter (He Fenqi and Zhang Yinsun, 1992); then in 1993 the Brownheaded established its own colony, of 15 nests, between the colonies of the Relict and the Gull-billed Tern; and in 1994, it had a separate colony of 15 nests together with another 15 nests mixed in the Relict Gull's colonies. Hence it brought with it a convincing solution to the former argument and suggestion on if the Relict Gull being a separate species as well as the relationship between it and the Brown-headed or/and the Great Black-headed (Vaurie 
1962, Dement' yev 1951, Zhang Yinsun and He Fenqi 1994).

\section{$4 \quad$ Wetland habitat assessment}

On 31st March 1992, the Chinese government delivered to UNESCO an official application for acceding to the Convention on Wetlands of International Importance especially as Waterfowl Habitat (the Ramsar Convention), and then on 31st July of the year was accepted as the 67 th contract nation of the Convention.

On the Convention contract parties' Regina Conference (Canada 1987), a revised Criteria for the identification of wetlands of international importance was adopted and recommended, and some relevant articles are excerpted as follows:

1. Criteria for assessing the value of representative or unique wetlands. A wetland should be considered internationally important if it is a particularly good example of a specific type of wetland characteristic of its region. A wetland could be considered for selection under this criterion if:

......

$1 \mathrm{~b}$ : it is a particularly good representative example of a wetland characteristic of the appropriate region;

2. General criteria for using plants or animals to identify wetlands of importance.

A wetland should be considered internationally important if:

2a: it supports an appreciable assemblage of rare, vulnerable or endangered species or subspecies of plant or animal or an appreciable number of individuals of any one or more of these species;

.......

3. Specific criteria for using waterfowl to identify wetlands of importance.

A wetland should be considered internationally important if:

3a: it regularly supports 20000 waterfowl;

$3 \mathrm{~b}$ : it regularly supports substantial numbers of individuals from particular groups of waterfowl indicative of wetland values, productivity or diversity;

$3 \mathrm{c}$ : where data on populations are available, it regularly supports $1 \%$ of the individuals in a population of one species or subspecies of waterfowl.

For more convenience, we here simply start at the specific criteria to discuss the value and importance of the T-A Nur:

4.1 Results of previous studies indicate that the Relict Gull Ordos subpopulation is worldwidely the largest local population of the species, with $2880,3820,3400$, and 4914 individuals by our census during 1991 1994 respectively, being in a proportion of at least more than $25 \%$ of the whole size as so far known of the bird in nature (He Fenqi et al. 1992, Zhang Yinsun et al. 1993).

And the T-A Nur is of specific significance to the breeding flock of the subpopulation: in 1991, it supported 44\% individuals in the flock, then in 1992 when Aubai Nur, another important breeding site of the Relict Gull on Ordos highland, was thoroughly drying out, it supported more than $90 \%$ breeders of the subpopulation * . Later on in 1993 1996, it supported the whole breeding flock (of 1509, 1931, 1832, and 2048 nests).

According to the indirect data so far obtained, the T-A Nur has been as the breeding habitat of the gull for at least more than thirty years (Zhang Yinsun and He Fenqi, 1993).

In view of the above, the T-A Nur is in line with the Criteria's Article 3c.

4.2 The Relict Gull, once was considered as an endangered species in the Red Data Book

* The total nests of colonies of the Relict Gulls at T-A Nur in 1990-1992 were 581, 491, and 1028 of each year; the Aubai Nur colony was found in 1991( 624 nests) with no information before 
both of IUCN and ICBP (King(ed.) 1979, 1981), later on it was treated degradedly as a rare bird (IUCN 1988) or a bird under threaten (Collar and Andrew 1988, Collar et al. 1994).

Anyway, on the maintaining capacity that the T-A Nur shows to the Relict Gull, it meets Article 2a.

4.3 And, moreover, in viewpoint of a locality of wetland habitat, the T-A Nur, within $100000 \mathrm{~km} \mathrm{sq}$. the whole range of the Ordos Highland, is of prominent significance to those wetland birds especially the waterfowl, namely:

4.3.1 It is the most important breeding habitat for the wetland birds in Ordos with 17 species of breeders there which is the highest record of the region;

4.3.2 It is, amongst all the wetland habitats in Ordos, of the highest bearing capacity to wethand birds, in fact the species found there occupying $94 \%$ of all those birds recorded in Ordos, while it is also of the highest bearing capacity of the biomass per unit area;

4.3.3 It is also functioning as a sanctuary maintaining some other threatened birds such as the Oriental White Stork, the Pallas's Sea Eagle, and the White-tailed Sea Eagle, to those birds, records in Ordos are occurring at the T-A Nur only;

4.3.4 It is, amongst those more than 100 lake habitats in Ordos, as one of the quite few localities bearing with a thoroughly independent wetland bird community, that is, a locality being such a habitat not only having its own independent breeding flock but also admitting an appreciable number of passengers/vagrants during the migrating season, not only maintaining the bird community of its own but also the birds of the surrounding satellite lakes, and hence evolving a rather stable and characterized desert wetland bird community;

4.3.5 It is as one of the quite few habitats in relatively high stability in the Ordos upland desert environment-under such an environment most wetland habitats, though in certain years can provide to wetland birds good habitats for inhabiting and breeding, are much changeable and strongly restricted by the annual rain fall, while the T-A Nur has some area of deep water and also with relatively high level of the underground water supply resisting dry season.

And therefore, according to the Criteria Article 1b, "it is a particularly good representative example of a wetland characteristic of the appropriate region".

\section{Conclusion}

Upon all the description above, the authors thought that the Taolimiao-Alshan Nur, following the relevant articles of the Criteria recommended by the Ramsar Convention for the indentification of wetlands of international importance, might be doubtlessly considered as a wetland locality in China of specific importance for the waterfowl and hence to be selected onto the List of Wetlands of International Importance, together with an urgent need of scheming the action plan on its wise use and soon to promote it into practice.

\section{REFERENCES}

Collar N J, P Andrew, 1988. Birds to watch - the ICBP world checklist of threatened birds. Cambridge: ICBP Tech. Publ., No. 8

Collar N J, Crosby M J, Stattersfield A J, 1994. Birds to watch 2- the world list of threatened birds. Bird 


\section{Internat.}

Dement'yev G P, 1951. Birds in Soviet Union. Moscow, Vol. 3 (in Russian)

Duff D G, Bakewell DN, Willisms M D, 1991. The Relict Gull (Larus relictus) in China and elsewhere. Forktail, $6: 43-65$

He Fenqi, Zhang Yinsun, 1992. Colonial breeding of the Brown-headed Gull and the Relict Gull from the Ordos highland of Inner mongolia, China. Bull. Ori. Bd. $\mathrm{Cl}$, 16: 39

He Fenqi et al., 1992. The distribution of the Relict Gull (Larus relictus) in Maowusu Desert, Inner Monglia, China. Forktail, 7:151 - 154

He Fenqi, Zhang Yinsun, 1993. Excellent year for breeding birds at Taolimiao-Alashan Nur, China. Bull. Ori. $\mathrm{Bd}, \mathrm{Cl}, \mathrm{18}: 18$

He Fenqi et al., 1994. The latest news on the Relict Gull Ordos population. Chinese Biodiversity, 2(2):88 $\sim 90$ (in Chinese)

IUCN, 1988. 1988 IUCN red list of threatened animals. Gland, Switzerland

King W B (ed. ), 1979. Red data book 2. Vol. 2, Aves. IUCN 1110 Morges, Switzerland

King W B (ed. ), 1981. Endangered birds of the world. Wash. D C: Smithson Instit. Press

Scott D A (ed.), 1989. A directory of Asian Wetland. IUCN, ICBP \& IWRB, Cambridge: Cambridge University Press.

Vaurie C, 1962. The status of Larus relictus and of other hooded gulls from central Asia. Auk, 79:303 309

Zhang Yinsun et al., 1991a. A new finding of the breeding population of the Relict Gull in Ordos. Chinese J. Zool. 26(3): 32 - 33 (in Chinese)

Zhang Yinsun et al., 1991b. Recent records of the Relict Gull (Larus relictus) in western Nei Mongol Autonomous Region, China. Forktail, 6:66 67

Zhang Yinsun et al., 1992. Breeding ecology of the Relict Gull (Larus relictus) in Ordos, Inner Mongolia, China. Forktail, 7:131-137

Zhang Yinsun et al., 1993. Studies on eco-biology of the Relict Gull's Ordos population. Sci. Treat. Syst . \& Evolut. Zool . 2:19 - 30 (in Chinese)

Zhang Yinsun, He Fenqi, 1992. Recent records of the Oriental Stork from China. Bull. Ori. Bd. Cl., $16: 45$

Zhang Yinsun, He Fenqi, 1993. A study of the breeding ecology of the Relict Gull Larus relictus in Ordos, Inner Mongolia, China. Forktail, 8:125 - 132

Zhang Yinsun, He Fenqi, 1994. On the taxonomic status of the Relict Gull (Larus relictus). Acta Zootaxon. Sini., 19(3): 378 382 (in Chinese) 